\title{
Eritapainen toimijuus koulutusvalinnoissa ja työelämässä
}

Tarkastelemme eri-ikäisten aikuisten koulutusvalintoja ja kokemuksia työelämästä. Pohdimme toimijuuden rakentumista sukupuolitapaisten toistojen tuloksena koulutuksessa ja työelämässä. Sukupuoli ohjaa usein valitsemaan sille merkittyjä koulutusaloja ja työtehtäviä. Kun toimijat ajatellaan samankaltaisiksi sukupuolen määrittämänä, uusinnetaan samalla yhteiskunnassa vallitsevia odotuksia. Erilaisten ja eritapaisten valintojen kautta on kuitenkin mahdollista purkaa tai muuttaa vallitsevia toimijuuksia määritteleviä diskursseja. Ensimmäinen aineistomme sisältää aikuisten kirjoitelmia ja haastatteluja, toinen koostuu varhaiskasvatuksen opettajaopiskelijoiden portfoliokirjoituksista. Luimme aineistoja ristiin toimijuusanalyysiin liittyvien modaliteettien täytyä, voida, tuntea, haluta, kyetä ja osata avulla. Kysymme, 1) millä tavoin sukupuolitapaisuus ohjaa koulutusvalintoja ja työelämän käytäntöjä ja 2) millaisilla modaalisilla ehdoilla valinnat mahdollistavat eritapaisen toimijuuden. Tulosten mukaan ymmärrystä sukupuolitapaisuudesta voidaan laajentaa, ja eritapaisuus voidaan nähdä toimijuuden mahdollisuutena sekä vastarintana odotetuille ja normitetuille valinnoille. Tutkimuksemme osoittaa, että koulutuksen ja työelämän vakiintuneita käytäntöjä kohtaan esiintyy tottelemattomuutta ja epäilyä. Samanaikaisesti tuloksemme paljastavat kahlittuja sukupuolittuneita tiloja, joissa mukaudutaan perinteisiin, diskursiivisiin toimijuuksiin.

Asiasanat: eritapaisuus, koulutus, modaalisuus, sukupuoli, sukupuolitapaisuus, toimijuus, työelämä

Aikuiskasvatus 41(4), 306

\section{Agency in education and career choices when doing gender differently}

The article (in Finnish) examines the educational and career choices of adults in different ages, focusing on how the iterative process of gender practices impacts the construction of agency in training and employment. Choices of field of study and work are often guided by the gender. When persons are considered similar based on the same gender, the existing expectations are being reproduced in the society. However, doing gender differently makes it possible to dismantle or change the discourses defining agency. One of our data sets consists of texts by and interviews of adults, the second of portfolio texts written by teacher students of early childhood education and care. We cross-read the material applying the six modalities of agency: ability, obligation, opportunity, feeling, desire and competence. Our questions are 1) how gender performance guides choices of fields of study and practices at work, and 2) which modalities enable choices based on alternative ways of doing gender. The results showed that understanding of gender performance can be widened and doing gender differently can be seen as an opportunity of agency and as resistance to expected normative choices. Disobedience to and doubt over established practices in education and work does occur, but the results also revealed existence of constrained gendered spaces where one adapts to traditional, discursive agencies.

Keywords: education and training, modality, gender, agency, working life, doing gender differently, gender performance

Aikuiskasvatus 41(4), 306 


\section{Toimijuuden ja identiteetin yksilölliset ja sosiaaliset painotukset korkeakoulutettujen urapoluilla}

Tarkastelemme tutkimuksessa toimijuutta ja identiteettiä korkeakoulutettujen uratarinoissa. Korkeakoulutettujen urapolkuja tutkimalla tunnistamme sekä korkeakoulutettujen urien rakentumisen tapoja että yksilön ja yhteiskunnan asettamien odotusten ja tavoitteiden merkitystä urapoluilla. Aineisto koostui Töissä.fi-verkkopalvelun kautta kerätyistä korkeakoulutettujen uratarinoista $(\mathrm{N}=462)$. Tutkimusaineiston narratiivisessa analyysissa tarkastelimme, millaisia urapolkuja uratarinoista oli tunnistettavissa sekä millaisia toimijuuden ja identiteetin yksilöllisiä ja sosiaalisia painotuksia uratarinat sisälsivät. Analyysin pohjalta loimme seitsemän uratyyppitarinaa, jotka nimesimme urapolun rakentumista kuvaavalla tavalla. Uratyypit olivat 1) suunnitelmalliset, 2) osaamisen tunnistajat, 3) aktiiviset, 4) sattuman kuljettamat, 5) intohimon ohjaamat, 6) polveilijat ja 7) yrittäjähenkiset. Uratyyppitarinat kuvaavat, kuinka korkeakoulutettujen toimijuus ja identiteetti olivat uratarinoissa eri tavoin yksilöllisesti tai sosiaalisesti painottuneita. Toimijuuden ja identiteetin painottuminen kuvasti sitä, miten yksilöllisesti tai sosiaaliseen yhteisöön nojautuen eri uratyypit tekivät omaa uraa koskevia valintoja sekä määrittivät, mitä he halusivat olla työssään. Tulokset osoittavat korkeakoulutettujen urapolkujen moninaisuuden. Samalla ne luovat pohjaa sille, miten sekä koulutus- ja työllisyyspolitiikassa että koulutuksen ja ohjauksen kentillä voidaan tunnistaa ja tukea erilaisia korkeakoulutettujen urapolkujen rakentumisen tapoja.

Asiasanat: toimijuus, identiteetti, korkeakoulutetut, urat, työura, narratiivinen analyysi

Aikuiskasvatus 41(4), 319

\section{Individual and social emphases of agency and identity as reflected in the career paths of higher education graduates}

In this narrative study, we investigated agency and identity in the career stories of higher education graduates. The career stories were analyzed to identify the various kinds of career paths, and the stories' emphasis of agency and identity. The data consisted of 462 career stories, gathered through the online service Töissä.fi. Based on the narrative analysis, we created seven career types with names describing the style of their construction: 1) Systematic, 2) Competence-driven, 3) Active, 4) Happenstance, 5) Passion-driven, 6) Meandering, and 7) Entrepreneurial.
The individual vs. social emphasis in agency and identity differed from one career type to another. The wide range of the career types presented in the article increases awareness of the diversity of career paths, thus supporting future development of career guidance, education policy, and employment policy.

Keywords: agency, identity, higher education graduates, career, narrative analysis

Aikuiskasvatus 41(4), 319 


\section{Yhteisöllinen luovuus ja ekspansiivinen oppiminen harjoittelukoulun Muutoslaboratoriossa}

Kulttuurihistoriallisen toiminnan teorian näkökulmasta luovuus ei näyttäydy vain yksilön kognitiivisena ilmiönä vaan yhteisöllisenä toimintana, joka tähtää jaettujen käytäntöjen uudistamiseen. Yhteisöllisen luovuuden on havaittu kytkeytyvän tiiviisti yhteisöllisen oppimisen muotoihin. Toiminnan teoreettisia empiirisiä tutkimuksia luovuuden ja oppimisen yhtymäkohdista on silti niukasti. Esittelemme tapaustutkimuksen suomalaisesta harjoittelukoulusta, jossa oli ilmennyt jännitteitä ja konflikteja tulevan opetussuunnitelmauudistuksen myötä. Ekspansiivisen oppimisen teoriaan pohjautuvassa Muutoslaboratorio-kehittämishankkeessa opettajaryhmä kehitti koululle uuden pedagogisen tiimityöskentelyn ja johtamisen toimintamallin. Tutkimme, millaisia luovia tekoja Muutoslaboratoriossa ilmeni, ja millä tavoin yhteisöllinen luova prosessi edisti osallistujien ekspansiivista oppimista.
Havaitsimme "luovia harppauksia": uudenlaisia työtoiminnan käsitteellistyksiä, jotka muodostuivat vuorovaikutuksessa yksittäisten luovien tekojen ketjuista. Ne saivat alkunsa työtoiminnan analysoinnissa esiin nousseista ristiriidoista ja tukivat ryhmän ekspansiivista oppimista tarjoamalla ristiriitoihin luovia ratkaisuaihioita. Kehittämällämme analyysimenetelmällä yhteisöllistä luovuutta voidaan tarkastella ekspansiivisen oppimisen taustalla vaikuttavana mikrotason vuorovaikutusprosessina. Tuloksia voidaan hyödyntää esimerkiksi koulutusorganisaatioiden muutosprosesseissa.

Asiasanat: ekspansiivinen oppiminen, kulttuurihistoriallinen toiminnan teoria, Muutoslaboratorio, opettajankoulutus, yhteisöllinen luovuus

Aikuiskasvatus 41(4), 333

\section{Collective creativity and expansive learning in the Change Laboratory at a teacher training school}

From the perspective of the Cultural-historical activity theory (CHAT), creativity appears not only as a cognitive phenomenon of an individual, but also as a collective activity aimed at renewing shared practices. Collective creativity and various forms of community learning have been found to be closely linked. However, activity-theoretical empirical research on the intersections of creativity and learning is still rare. We are presenting a case study from a Finnish teacher training school where tensions and conflicts had emerged because of the forthcoming curriculum reform. The school implemented a development project utilizing Change Laboratory, based on the theory of expansive learning, where a group of teachers created a new model for the school's pedagogical teamwork and leadership. We explored the creative interaction taking place during the Change Laboratory, and how the collective creative process benefited the participants' expansive learning. 'Creative leaps' were observed: new conceptualizations of work activity emerged as individual creative actions accumulated in interaction. They were initiated by the conflicts identified in the work activity, and they supported the group's expansive learning by offering tentative solutions to the conflicts. We developed a method of analysis that allows looking at collective creativity as a micro level process of interaction that is impacting in the background of the expansive learning. The results can be utilized in planning and implementing processes of change in educational organisations.

Keywords: Change Laboratory, collective creativity, cultural-historical activity theory, expansive learning, teacher training

Aikuiskasvatus 41(4), 333 